\title{
Spain in Crisis: 15-M and the Culture of Indignation
}

\author{
Bryan Cameron \\ Department of Spanish \& Portuguese \\ University of Cambridge, United Kingdom
}

"Nos encontramos ante un panorama sin ninguna esperanza y sin un futuro que nos incite a vivir tranquil@s y poder dedicarnos a lo que nos gusta a cada un@"

- Comunicado de los detenidos de la manifestación del 15 mayo de 2011

$$
\begin{gathered}
\text { "Es necesaria una Revolución Ética" } \\
\text { - Manifiesto }<<\text { Democracia real ya }>>(15 / 05 / 2011)
\end{gathered}
$$

2011 already stands as a decisive year in the transformation of modern political culture. As a series of protest movements erupted worldwide in the spring and summer of 2011, an unprecedented number of global citizens found new ways to vocalize their indignation against governmental leaders and plutocrats (the so-called $1 \%$ ) while advancing counterhegemonic strategies within the framework of primarily nonviolent mobilizations. ${ }^{1}$ Interrogating the legitimacy of the elite in a wide range of political and economic contexts, movements such as the Arab Spring (18 December 2010), the Greek Aganaktismenoi (5 May 2010), Iceland's Kitchenware Revolution (20 January 2009), Israel's J14 (14 July 2011), Occupy Wall Street in the United States (17 September 2011), Portugal's Geração à Rasca (12 March 2011), and Spain's 15-M (15 May 2011) animated a chain of "democratic awakening[s]" while striving to formulate new modes of activism amongst predominantly depoliticized populations (West). These newly envisaged paradigms of combative politics confronted two discrete yet inextricably linked issues within a global context. First, they called for political reforms in an effort to (re)construct democratic processes, most dramatically in countries such as Egypt, Libya, Morocco, Syria, and Tunisia. Second, they expressed widespread resentment for neoliberal practices that have intensified income inequality and expanded the precariat, ${ }^{2}$ an emerging social class doomed to endure "insecurity, uncertainty, debt and humiliation" (Standing, The Precariat vii). The massive outpouring of discontent, particularly in nations such as Belgium, France, Greece, the United Kingdom, the United States, and Spain, also took aim at governmental corruption and the inept mishandling of economic crises (e.g., the implementation of austerity measures and the privileging of debt payments over health care and entitlement benefits). ${ }^{3}$ Galvanized by a politics of

\footnotetext{
${ }^{1}$ In both Superclass and Power, Inc., David Rothkopf studies a global elite comprised of 6,000 "supercitizens" "whose daily decisions redirect massive assets among markets; create, dislocate, or eliminate jobs around the globe; determine the viability of government programs and sometimes of governments; and also play a vital role in shaping the global era" (Superclass xxiii).

${ }^{2}$ See Jean-Claude Barbier's "Precarious Employment in Europe," Lauren Berlant's Cruel Optimism, Guy Standing's A Precariat Charter: From Denizens to Citizens, and Vassilis Tsianos and Dimitris Papadopoulos' "Precarity: A Savage Journey to the Heart of Embodied Capitalism" for more on precarity and the precariat.

${ }^{3}$ See "Austerity: A Failed Experiment on the People of Europe" by Martin McKee, Marina Karanikolos, Paul Belcher, and David Stuckler for a scathing critique of budgetary reform that now structures - by royal
} 
indignation, ${ }^{4}$ the 2011 wave of protest movements will live on for many years in the political memory of these nations as a major step in combatting the social conflict of polities riven by economic and political crises. But what are the political and cultural gains made by these movements? What challenges will they face moving forward? This special issue, by centering on the 15-M Movement in Spain, examines the "cambio radical de escenario" generated in Spain since May of 2011 and the interpersonal and collective expression of affective experience in the wake of a seemingly interminable crisis (Fernández-Savater, "No una opinión, sino un ramillete de voces" 24$){ }^{5}$

By challenging the confines of the post-political society, ${ }^{6}$ both nationally and transnationally, the chain of worldwide mass mobilizations continues to question the individualist ideology of neoliberal praxes and insist upon the return of the political in societies governed by corrupt or incompetent leaders who blatantly cater to the interests of "the 'top 1\%' while remaining astonishingly aloof from popular distress" (Perugorría and Tejerina 425). ${ }^{7}$ As Chantal Mouffe has argued, the political denotes critical practices "that aim at fomenting dissensus [while] bringing to the fore the alternatives repressed by the dominant hegemony" ("Interview" 234). ${ }^{8}$ Movements such as the Spanish 15-M destabilize "the symbolic representation of society as an organic body" through dissent, disagreement, and confrontation in an effort to envisage a democratic order undergirded by a conflictual consensus between adversaries (Mouffe, "Deliberative Democracy or Agonistic Pluralism" 16). The result of a three-tiered process, the 15-M Movement has been able to imagine distinct models of citizenship by first inscribing a radical negativity in the political domain through the public shaming of corrupt or negligent legislators (escraches), the occupation of public space, and the systemic and electoral demands mandated by ¡Democracia real YA! (¡DRY!) and the Movimiento Ciudadano por el Voto en Blanco (MCxVBC) respectively. Second, by usurping politics from a delinquent governmental regime (through the multifarious mareas, public assemblies, Plataforma de Afectados por la Hipoteca [PAH], Stop Desahucios, etc.), the 15-M has effectively re-

decree - welfare and entitlement programs based on employment status. The consequences of these austerity measures exclude large numbers of the populace from public benefits including "undocumented migrants and young people who have never been employed, a potentially serious situation in Spain where over half of all youth are unemployed" (348).

${ }^{4}$ I borrow the term from Mario Espinoza Pino's essay titled "Politics of Indignation: Radical Democracy and Class Struggle Beyond Postmodernity," which brilliantly cites the following quote from Karl Marx's Revolutionary Spain to make a case for Spain's historic resilience: "Thus is happened that Napoleon, who, like all his contemporaries, considered Spain as an inanimate corpse, was fatally surprised at the discovery that when the Spanish State was dead, Spanish society was full of life, and every part of it overflowing with powers of resistance" (qtd. in Espinoza Pino 228).

${ }^{5}$ See Isidro López and Emmanuel Rodríguez's "The Spanish Model" for more on the financial complexities of the Spanish Crisis.

${ }^{6}$ In books such as Agonistics, The Democratic Paradox, On the Political, The Return of the Political, Chantal Mouffe critiques the neutralizing procedures of post-political discourse, which rejects conflict, dissent, and the mobilization of "political passions" in an effort to eliminate the tensions that exist between liberalism and democracy (Agonistics 59)

${ }^{7}$ See Chrystia Freeland's Plutocrats for more on what she claims is actually the $0.1 \%$, or "global high rollers," who shape political, economic, and social policy across the planet without regard for national allegiance (3).

${ }^{8}$ For Mouffe, 'the political' signifies "the ontological dimension of antagonism" whereas 'politics' alludes to "the ensemble of practices and institutions whose aim is to organize human existence" (Agonistics xii). 
appropriated tasks that might have otherwise been managed by the state in an effort to protect and secure public services and the right to affordable housing against the individual and collective devastation caused by Spain's austerity policies. ${ }^{9}$ Finally, by fostering the emotional liberation of the populace from current forms of distress (e.g., creative expression through the Free Culture and Digital Commons Movement, ${ }^{10}$ flash mobs in unemployment offices, ${ }^{11}$ dance performances in banks, ${ }^{12}$ etc.), the $15-\mathrm{M}$ emphasizes a non-elitist, horizontal approach to collaborative culture that short-circuits neoliberal ideology (shaped by competition and individualism) in favor of a collective model, effectively redefining what Amador Fernández-Savater has described as "los límites de lo posible" in crisis-ridden Spain. ${ }^{13}$

The process of emotional liberation, a term coined by Helena Flam, represents a key component of the 15-M's project, as it facilitates the relaxation and eventual obliteration of outmoded affective attachments that have linked Spaniards to hegemonic parties (PP, PSOE, ${ }^{14}$ etc.) since the Transition to democracy. ${ }^{15}$ In the Spanish case, the fabrication of new sentimental ties, or, at minimum, a fleeting affection for new political vehicles such as Partido X or Podemos, evinces the public's dissatisfaction with stagnant parliamentary politics and its reticence to gamble its financial interests and the future of healthcare and other entitlement benefits on the volatility of market speculation and the corrupt (mis)management of the Crisis by financiers and governmental leaders alike. The attempt to construct new emotional bonds, based on trust and respect, has serious political implications as citizens contemplate their affective "loyalty to and gratitude toward authorities," which both have a potentially "dampening effect on protest" movements (Benski and Langman 10). ${ }^{16}$ Obviously, when the public assumes that its government will represent its best interests without pressure from the outside (protests, public shaming, media exposés, etc.), the emergence of emotional responses such as anxiety, outrage, and depression are much less likely to surface. For the Spanish populace, however, rampant dissatisfaction with the monarchy, parliamentary practices, police abuse, and budget cuts that endanger physical and mental health as well as the ability to gain employment and

\footnotetext{
9 See Germán Labrador Méndez’s "Las vidas subprime."

${ }^{10}$ See Mayo Fuster Morell's "The Free Culture and 15M Movements in Spain: Composition, Social Networks and Synergies" for more.

${ }^{11}$ The cover image of this special issue explicitly references Solfónica's flashmob performance of The Beatles' "Here Comes the Sun," which was performed in an unemployment office in Madrid in January of 2013. (https://www.youtube.com/watch?v=XoBMJAEOvPA)

${ }^{12}$ See the following link for Flo6x8's flamenco flash mob in an Andalusian bank: (https://www.youtube.com/watch?v=Y7yk8Prgp10)

${ }^{13}$ As part of his contribution to this edited volume, Luis Moreno-Caballud examines Fernández-Savater's employment of this term. See Fernández-Savater's "Emborronar la CT (del $<<$ No a la Guerra $>>$ Al 15-M)" for more.

${ }^{14}$ In an interview with the New York Times, Pablo Iglesias, the head of Podemos and newly elected Member of European Parliament, articulates the need for new paradigms in Spanish politics thusly: "I've always been from the left but our problems cannot be explained in terms of left-right ideology, but in terms of fighting the privileged that are abusing the majority of citizens below them" (Minder).

${ }^{15}$ Slogans such as "¡PSOE y PP, la misma mierda es!” speak to the exhaustion of the two-party hegemony and the need to fashion democratic discourse based on interests that are truly oppositional in nature.

${ }^{16}$ See Jo Labanyi's "Doing Things: Emotion, Affect, and Materiality" for an excellent primer on "the recent 'affective turn' in cultural studies" in which she argues for "more work [...] in Spanish cultural studies on practices rather than texts" $(223 ; 229)$.
} 
affordable housing, have undoubtedly generated a culture of indignation since the early days of the global financial collapse of 2008.

Inspired in part by Stéphane Hessel's Indignez-vous! (2010), ${ }^{17}$ the $15-\mathrm{M}$ Movement has managed to expose the collusion between politicians and bankers while (re)imagining paradigms of democratic citizenship that center on seemingly contradictory principles (outrage, harmony, disaffection, respect, care, ludic strategies, etc.). ${ }^{18}$ Nevertheless, these discrepancies, as Mouffe argues, are needed to cultivate a multipolar environment, in which a number of political channels provide opportunities to critique the neoliberal model of globalization and, as a result, foment a "vibrant clash of democratic political positions" by debating policy and not identity politics ("Deliberative Democracy or Agonistic Pluralism" 16). Veering away from the old model of doing politics, the central question is now "What do we want to change?" not "Which hegemonic party is best equipped to effect that change?" The 'official' model of parliamentary politics, steeped in ideological taxonomies that have continued to impose an illusory binary, no longer serves the interests of a population that is now highly skeptical of unions and traditional leftist parties. The efforts, therefore, of the 15-M and the multiple splinter groups it has come to represent unofficially should be considered culturally significant as an innovative mode of (re)constructing democracy in Spain despite the fact that the movement does "not have [an official] program" (Castells 122). ${ }^{19}$ The lack of an 'authorized' program, of course, has been crucial to the movement's success. ${ }^{20}$ Circumventing the decayed rhetoric of 'official' political discourse, the 15-M managed to promote a collective heteronomy by evading the parliamentary system and calling for "the transformation of pseudodemocracy into a real democracy" (Castells 124). ${ }^{21}$

\footnotetext{
${ }^{17}$ The release of WikiLeaks documents in November of 2010 cannot be underestimated as an animating force for the most internet-savvy contingent of the \#spanishrevolution.

${ }^{18}$ Historians' interpretations of democracy in Spain vary wildly. Richard Gunther, P. Nikiforos Diamandouros, and Hans-Jürgen Puhle have claimed that Spain (in the 1990s) showed "signs of Democracy Lite" plagued by "[c]ivic anemia [...] and extraordinarily low levels" involvement with politics (22). Nevertheless, Bonnie N. Field and Kerstin Hamann argued in 2008 that "Spain therefore should no longer be considered an exceptional case and should be included in cross-national studies of advanced democracies" (216).

${ }^{19}$ This point is crucial. The term 15-M clearly refers to the date on which tens of thousands of protestors descended upon and occupied public plazas throughout Spain. Castells provides specific details regarding participation in his essay "A Rhizomatic Revolution": "Madrid (50,000), Barcelona (20,000), Valencia $(10,000)$ and 50 more cities, peacefully, without any major incident anywhere" (112). Nevertheless, despite the volume of people engaged in strategies of occupation, the ideological coherence of the movement has always been questioned, as participants were animated by an array of splinter groups such as x.net, Anonymous, Nolesvotes, Estado del Malestar, Juventud Sin Futuro, Juventud en Acción, Plataforma de Afectados por la Hipoteca whereas others sought to challenge the internet restrictions imposed by the Ley Sinde or inspired by the possibility of (re)defining ¡Democracia real YA!.

${ }^{20}$ Moreno-Caballud excoriates the authority of so-called experts who, in spite of their status as "los que saben," have somehow mismanaged Spanish policy in his essay "Podemos: la crisis de un modelo cultural autoritario."

${ }^{21}$ The ruptura pactada of the 1970s, undoubtedly, shaped current conceptions of democracy in Spain, as McDonogh, Barnes, and López Pina claim: "The authoritarian system and the democratic regime that followed it are not mirror images. Democratization was gradual rather than abrupt. The nonrevolutionary nature of democratization leaves open the possibility of a selective, less-than-total separation between the
} 
Nevertheless, the affective dimension of any type of political identification (whether new or old) can pose certain threats to the coherence and long-term viability of a productive democratic project. As Freud claims in Group Psychology and the Analysis of the Ego, "a group is clearly held together by a power of some kind" (30), which he subsequently identifies as Eros. Collective identities, crucially, always rely upon the articulation of a "we," which, should be viewed as "the result of a passionate affective investment that creates a strong identification among the members of a community" (Mouffe, Agonistics 46). These emotional ties, mobilized by libidinal instincts, forge passionate relations between members of the same collective, ultimately establishing a key distinction in identitarian terms between "us" and "them". Despite its overtly inclusive rhetoric from the outset, ${ }^{22}$ it must be said that the 15-M reproduced part of the logic of the 'old way' of doing politics by pitting one side (the $99 \%$ ) against another (the $1 \%$ ). ${ }^{23}$ Mouffe, channeling Freud's work in Civilization and Its Discontents, ${ }^{24}$ points out that the problem of such a confrontation (between an "us" and a "them") is that, much like the political and economic confines from which the 15-M has sought to extricate the Spanish people, the language of unity or consensus - expressed through images of love, dignity, and pride, ${ }^{25}$ for instance - may ultimately stifle future participation. Mouffe proposes that instead of "binding all citizens to one another in an image of unity, the problems of the political common" may be best addressed by pitting "some against others in a web of allegiances and conflicts" in order to tackle the democratic deficit afflicting much of the European Union (57). That said, in stark contrast to the conception of a deliberative democracy envisioned by John Rawls and Jürgen Habermas, Mouffe emphasizes the need to rethink an outdated brand of "pluralism whose legitimacy is only recognized in the private sphere [that] has no constitutive place in the public domain" ("An Agonistic Approach to the Future of Europe" 637). According to Mouffe, the employment of public space and open-access forums (agoras, plazas, encampments, open-air theatres, inclusive assembly meetings, Free Culture and the Digital Commons, etc.) is essential for the presentation of dissenting points of view where the very notion of consensual reconciliation (a rationalist 'right' or 'wrong') must be dispelled.

While defying the logic of institutional politics, one of the most striking successes of the 15-M Movement has been its ability to (re)envision "la cultura como un "procomún"” which has, in turn, managed to generate "una 'imaginación sostenible" in Spain by stimulating new modes of aesthetic and intellectual production over the last four years (Moreno-Caballud, "La imaginación sostenible" 535). Several of the contributors

two" (33). One might wonder, then, if a radical \#spanishrevolution is required to install a more participative democratic regime.

${ }^{22}$ One of the proposals from the Acampada Sol (approved on 20 May 2011) dictates that "la Asamblea es un proceso abierto y colaborativo. Esta lista no debe entenderse como cerrada" (qtd. by Cabal 10).

${ }^{23}$ Evolving articulations of democracy should continue to balance an open-access ethos while promoting a Mouffian agonistic pluralism in order to avoid the "radicalization and the exclusion of the right," which Peter McDonough, Samuel H. Barnes, and Antonio López Pina argue (5), referring to Spain's Second Republic.

${ }^{24}$ As Freud argues, it "is always possible to bind quite large numbers of people together in love provided that others are left out as targets for aggression" (50).

${ }^{25}$ One might recall Basilio Martín Patino's exquisite documentary Libre, te quiero (2012), which stages the $15-\mathrm{M}$ protests, in the director's own words, as “una reacción hermosa y espontánea de la sociedad. Una conmoción colectiva, una fiesta" (García). 
featured within this special issue examine cultural production from the Crisis by studying the work of artists/activists who extend previously demarcated fields of artistic intervention beyond the scope of the neoliberal practices. For the vast majority of these artists/activists, who purposefully labor outside of traditional or 'official' cultural institutions, their work represents an attempt to produce new imaginaries and articulate alternative subjectivities in a time of crisis. Transferring the proliferation of collective empowerment to the sphere of parliamentary politics, however, has remained a sticking point for many critics of the 15-M who claim that the movement poses more problems than it resolves. In Hipótesis Democracia, for instance, Emmanuel Rodríguez argues that "el $15 \mathrm{M}$ como acontecimiento y verdad abre un problema que el 15M organizado no sabe resolver: ¿cómo se articula y se impone un movimiento constituyente? ¿cómo se tumba al régimen?, en definitiva, ¿qué democracia? (278). I would argue that, while the 15-M's political successes have yet to be determined, its most impactful contribution has been its capacity to galvanize the passions (in the Mouffian sense) of the Spanish people and, as a result, nurture diverse expressions of intellectual and artistic insurgency. Furthermore, one of the movement's most salient (and indisputable) objectives has been to undertake "[una] investigación coral sobre nuestra realidad en crisis y los modos de transformarla" (Fernández-Savater qtd. by Arjona). These modes of transformation, incited by the disparate and divergent interests of the Spanish people, succeeds in part merely by suspending the laws of competition that govern capitalist ideology and replacing them with a pro-commons approach to culture that may or may not ultimately imply a change in political regimes. The success, therefore, of the 15-M Movement has been its capacity to open up the realm of affects by decentralizing the role of the State and mobilizing a grassroots approach to horizontal, non-elitist conceptions of policy debate. In other words, the 15-M's issue-based fluidity has imbued the movement with a type of mobility that hegemonic political parties would never be able to fathom. One question persists, however, as critics posit conflicting responses to the 15-M: is the movement a precursor to the systemic overhaul of Spanish parliamentary politics or merely a fleeting expression of indignation doomed to fade away?

This double issue of the Journal of Spanish Cultural Studies celebrates the third anniversary of the 15-M Movement in Spain by grappling with the past, present, and future of the Indignad@s' project. The authors and respondents featured here examine the socio-political landscape of the Crisis from a variety of perspectives while emphasizing the fact that, for the vast majority of Spaniards, neoliberal policies have produced a strain of cultural pathology (due to the consequences of staggering unemployment, foreclosures and evictions, ${ }^{26}$ poverty and hunger, ${ }^{27}$ depression, ${ }^{28}$ and an increased suicide rate, ${ }^{29}$ etc.)

\footnotetext{
${ }^{26}$ See Vidas hipotecadas: de la burbuja inmobiliaria al derecho a la vivienda by Ada Colau and Adrià Alemany for more on how "[1]a ansiedad ante el inminente desahucio y la muerte financiera de las familias causa trastornos psicológicos graves" (32).

${ }^{27}$ See Germán Labrador Méndez's contribution to this dossier for more on the "exponential growth in poverty and hunger in Spain as a result of the crisis."

${ }^{28}$ See "Economic Crisis and Mental Health in Spain" by Miguel Roca, et al. and "The Mental Health Risk of Economic Crisis in Spain: Evidence from Primary Care Centres, 2006 and 2010" by Margarita Gili, et al. for more on the prevalence of mental disorders that have surfaced during or because of the Crisis.

${ }^{29}$ See "The Effect of the Late 2000s Financial Crisis on Suicides in Spain: An Interrupted Time-Series Analysis" by James A. Lopez-Bernal, et al. for more on Spain's escalating suicide rate. Curiously, these
} 
that can no longer be ignored by the State. Inspired by the collective and dialogic nature of the 15-M itself, the structure of this dossier reflects a collaborative methodology in which colleagues are placed in direct conversation with one another without regard for rank or status in the field. Moreover, the double issue seeks to replicate the horizontality of the 15-M while relying upon a keen sense of interdisciplinarity in order to address the multifaceted nature of the crises (employment, finance, housing, governance, politics, survival, etc.) afflicting Spain today.

The first four essays examine the current cultural climate in Spain by referring to Guillem Martínez's analysis of the culture produced in the aftermath of the Spanish Transition to democracy, which he terms the "Cultura de Transición. ${ }^{30,}$ For Martínez, the "CT," which he calls "un tapón cultural" that has plagued Spain for more than three decades, has obstructed the freedom of expression (both political and artistic) since the death of Franco. These ideas, rehearsed elsewhere by critics such as Patrick Paul Garlinger ("Sex Changes and Political Transitions," 2005) and Eduardo Subirats (Después de la lluvia, 1993), demonstrate that the promise of democracy in the late 1970s ultimately led to a falsified vision of a democratic state in Spain. Following Martínez's lead, Luis MorenoCaballud, in his essay "Cuando cualquiera escribe. El ecosistema de la 'Cultura Libre' como factor democratizador de las letras españolas en la crisis de la "Cultura de la Transición," contrasts the decay of the "CT" with the emergence of a "Cultura Libre" in Spain, spurred on by technological advances and new modes of communication that support an accessible flow of information and knowledge by opening up collaborative platforms for the creation and distribution of knowledge. Similarly, Pablo La Parra Pérez's essay "Revueltas lógicas: el ciclo de movilización del $15 \mathrm{M}$ y la práctica de la democracia radical" centers on the 15-M Movement's efforts to undermine the "CT" by (re)animating modes of civic and political activism that were so popular in the 1960s and 1970s under the Franco dictatorship. In "The Spanish 15-M Movement: A Consensual Dissent?," Víctor Sampedro and Josep Lobera scrutinize the findings of recent opinion polls regarding the public's perception of the 15-M Movement while pointing to the erosion of transitional culture in an attempt to distinguish the difference between the political and cultural potential of the 15-M's agenda. Kostis Kornetis' "'Is there a Future in this Past?': Analyzing 15M's Intricate Relation to the Transición" also ponders the 15M's ambivalence regarding the legacy of the Transition. Sifting through oral interviews with the hijos de la Transición and analyzing what he terms "Transición Syndrome," Kornetis argues that the fiction of a model Transition to democracy effectively (de)formed the political consciousness of an entire generation of Spaniards.

The dossier's second section, comprised of three essays, focuses on cultural production (cinema, theatre, cartography, and installation art) that reflects the 15-M's impulse to "pensar-crear" as a means of seeking liberation from the burdens of neoliberal hegemony (Fernández-Savater qtd. by Arjona). As a space of potential, whether affective,

findings conflict with the information released by the Spanish National Institute of Statistics (Instituto Nacional de Estadística), which reported that the suicide rate in Spain decreased between 2008-2011.

${ }^{30}$ The erosion of the "CT" has intensified following the abdication of King Juan Carlos I (19 June 2014) and the recent death of Adolfo Suárez (23 March 2014), Spain's first democratically elected Prime Minister, who both served as key players during and after the Transition to democracy. 
intellectual, ${ }^{31}$ political, and/or creative, ${ }^{32}$ the 15 -M Movement has undoubtedly broken open new sites of possibility for artists whose work speaks to the collective struggle of everyday life in the age of austerity. In "Prime Risks: The Politics of Pain and Suffering in Spain's Crisis Cinema," Dean Allbritton surveys an expanding category of filmic production, which he terms "crisis cinema." For Allbritton, films such as La chispa de la vida (Álex de la Iglesia 2011), 5 metros cuadrados (Max Lemcke 2012), and Los últimos días (Àlex Pastor and David Pastor 2013) expose the physical and psychic suffering of the precariat while articulating the perils of living in a perpetual state of crisis. In "The 15-M Movement: Formed by and Formative of Counter-Mapping and Spatial Activism," Stephen Luis Vilaseca analyzes spatial activism in La Barceloneta, a traditionally working-class neighborhood in Barcelona, by two neighborhood associations who reevaluate public space through "counter-mapping." Vilaseca also studies the work of the artistic team Gómez+González to further develop his study of space and memory and the capacity of art to test the limits of democratic participation during the Crisis. Finally, in "Don Juan Tenorio in the Campo de Cebada: Re-Staging Urban Space After 15-M," Matthew I. Feinberg also focuses on spatial relations by examining the outdoor theatrical performances of José Zorrilla's Don Juan Tenorio (1844) produced by AlmaViva Teatro in 2011 and 2012. As Feinberg argues, the participatory urbanism cultivated by AlmaViva Teatro's staging of the nineteenth-century classic asks spectators to engage with the privatization of public space in Madrid in an effort to confront the capitalist logic dominating the cultural landscape of the capital.

The dossier's third section explores evolving vehicles for linguistic expression as well as the messages themselves produced in the wake of 15-M both in public spaces and on Twitter. In "En \#Sol, revolución: paisajes lingüísticos para tomar las plazas," Luisa Martín Rojo and Carmelo Díaz de Frutos analyze the (re)appropriation of urban space by analyzing a series of images photographed during the occupation of the Puerta de Sol. Considering photos from an exhibition titled Madrid multilingüe. Lenguas pa la citi, Martín Rojo and Díaz de Frutos survey the distinct articulations of indignation and joy that appear on protest posters, t-shirts, and graffiti in the Plaza de Sol, underscoring the ways in which these slogans reshape our gaze as citizens by emphasizing the fluidity of urban space as well as the confluence of linguistic difference permeating the Spanish capital. Ismael Peña López, Mariluz Congosto, and Pablo Aragón's "Spanish Indignados and the Evolution of the 15M Movement on Twitter: Towards Networked Para-Institutions" tracks the usage of Twitter during peak moments of social mobilization during the 15-M Movement in an effort to demonstrate the internet's status as an extra-representational tool for political participation through which citizens are able to communicate, establish meaningful relationships, and, accordingly, cultivate networks of support and outrage. Focusing on the ways in which citizen-based movements utilize

\footnotetext{
${ }^{31}$ See Luis Martín-Cabrera's essay titled "The Potentially of the Commons: A Materialist Critique of Cognitive Capitalism from the Cyberbracer@s to the Ley Sinde" for more on the debate regarding "the different and powerful interests that are trying to determine who has access to culture and knowledge, and under what privatized conditions their access is possible on the Internet" (599).

${ }^{32}$ See Moreno-Caballud's "La imaginación sostenible: culturas y crisis económica en la España actual" for more on how the development of "redes de solidaridad, auto-organización, colaboración, denuncia y protesta, que se han movilizado activamente ante la crisis" have led to "la emergencia de todo un caudal de 'imaginación sostenible'" (537).
} 
the internet (Twitter, specifically) to reach followers, Peña López Peña, Congosto, and Aragón claim that websites such as Twitter bypass traditional or 'authorized' modes of political utterance and, accordingly, construct new foundations for innovative expressions of protest and participation.

The dossier's final section features two essays that both explore what it means to live in the time of crisis. In "About Time: Sensing the Crisis in Nophoto's El último verano," Jonathan Snyder argues that the current conditions of la crisis impose a temporal deadlock in which the everyday hardships associated with loss, precarity, and the downward turn of social mobility in contemporary Spain arouse nostalgia for the past, the search for another present, or fantasies of a better future. Juxtaposing Lauren Berlant's work on the impasse and images by the Nophoto photography collective, Snyder examines distinct ways of understanding time since the 2008 financial crash, as citizens confront the day-to-day hazards of multiple crises, which subtend modes of existence and ultimately render the present both "estranged and estranging." Similarly, Germán Labrador Méndez's "The Cannibal Wave: The Cultural Logic of Spain's Temporality of Crisis (Revolution, Biopolitics, Hunger and Memory)" argues that the 2008 financial crash suspended time in Spain, effectively provoking a "temporality of crisis (20082013)" imposed by the decline of the middle class, state-imposed recortes, privatization, and evictions. Labrador Méndez studies a range of cultural products such as television cooking shows (Pesadilla en la cocina), horror films (Canibal, Carne Cruda), documentary cinema (La matança del porc), public art (street adaptations of Goya's Saturn Devouring His Sons), and protest strategies (guillotines placed in front of Madrid's Palacio Real) to demonstrate the neoliberal domination of Spanish society and its methods of demarcating citizens as either producers or consumers. The concern with a temporality in crisis or the crisis of temporality, as Luis Martín-Cabrera contends in his response to Labrador Méndez, ultimately reveals that there can be no ethical return to the "“peaceful' times that preceded the crisis," as they were bound up in neocolonial systems of poverty, oppression, and labor exploitation. "Imagining recipes for a different future to come," as Labrador Méndez suggests, provides a fitting conclusion to this dossier, as it tacitly defends the utility of cultural studies (often attacked for being disengaged from the political) as a theoretical field still capable of articulating emancipatory projects and, in the case of the 15-M, implicated in the call for "una Revolución Ética" (Manifiesto $<<$ Democracia real ya $>>$ ).

\section{Acknowledgement:}

I would like to express my gratitude to Jo Labanyi, Georgina Dopico Black, and Mari Paz Balibrea for supporting this project. Mari Paz, in particular, was a key interlocutor throughout the process and I wish to thank her publicly for her generous feedback. Moreover, this dossier benefitted tremendously from a round table discussion and film series titled "Spain in Crisis: The Spanish Crash and the Indignados Movement," which Jo organized for the King Juan Carlos I of Spain Center at New York University in October of 2013. Many thanks go to Luis Moreno-Caballud, as well, for the inspiration. 


\section{Notes on Contributor:}

Bryan Cameron is University Lecturer at the University of Cambridge (Selwyn College) in the United Kingdom. His research centers on modern Spanish culture with a focus on literary, filmic, and ideological production from the eighteenth century to the present. Bryan has published essays on the nineteenth-century novels of Benito Pérez Galdós and Leopoldo Alas ("Clarín") in Decimonónica and Revista Hispánica Moderna. His current book-length project, Paternity Tests: Destabilized Authority in the Late-NineteenthCentury Spanish Novel, examines the allegory of literary parentage in novels by "Clarín," Vicente Blasco Ibáñez, Eduardo López Bago, Narcís Oller, Pérez Galdós, Alejandro Sawa, and José Zahonero following the decay of the liberal program launched by the Revolution of 1868. Bryan's previous teaching experiences include lecturing in the United States at the University of Pennsylvania, Bryn Mawr College, and New York University.

\section{Works Cited}

Abasolo, Olga, Jeremy Gilbert, Hilary Wainwright. "The Indignados and Us." Soundings: A Journal of Politics and Culture 57 (Summer 2014): 35-49.

Arjona, Daniel. "Amador Fernández-Savater: 'No nos dejemos arrebatar las preguntas que la crisis nos impone.” El Cultural 29 March 2013. Web. 27 February 2013.

Barbier, Jean-Claude. "Precarious Employment in Europe." Le Quatre Pages September 2002. Centre d'études de l'emploi. Web. 15 June 2014.

Benksi, Tova, and Lauren Langman. "The Effect of Affects: The Place of Emotions in the Mobilizations of 2011." Current Sociology 61.4 (July 2013): 525-540.

Berlant, Lauren. Cruel Optimism. Durham, NC: Duke UP, 2011.

Cabal, Fernando, ed. Indignados. Selección de materiales sobre el 15M. Madrid: Mandala Ediciones, 2013.

Castells, Manuel. "A Rhizomatic Revolution: Indignadas in Spain." in Networks of Outrage and Hope. Cambridge, UK: Polity, 2012. 110-155.

Colau, Ada and Adrià Alemany. Vidas hipotecadas: de la burbuja inmobiliaria al derecho a la vivienda. Barcelona: Angle Editorial, 2012.

Espinoza Pino, Mario. "Politics of Indignation: Radical Democracy and Class Struggle beyond Postmodernity." Rethinking Marxism 25.2 (2013): 228-241.

Fernández-Savater, Amador. "Emborronar la CT (del $<<$ No a la Guerra $>>\mathrm{Al} 15-\mathrm{M})$." in CT O La Cultura de la Transición: Crítica a 35 años de cultura española. Kindle edition. Ed. Guillem Martínez. Barcelona: Debolsillo, 2012. 
---. "No una opinión, sino un ramillete de voces." in Fuera de lugar. Conversaciones entre crisis y transformación. Ed. Amador Fernández-Savater. Madrid: Acuarela Libros \& Antonio Macho Libros, 2013. 9-29.

Field, Bonnie N., and Kerstin Hamann. "Conclusion: The Spanish Case and Comparative Lessons on Institutions, Representation, and Democracy." in Democracy and Institutional Development: Spain in Comparative Theoretical Perspective. Palgrave Macmillan: London, 2008. Eds. Field and Hamann. 203-21

Flam, Helena. "Emotions' Map: A Research Agenda." in Emotions and Social Movements. Eds. Helena Flam and Debra King. London: Routledge, 2005. 19-40.

Freeland, Chrystia. Plutocrats: The Rise of the New Global Super-Rich and the Fall of Everyone Else. New York: Penguin, 2013.

Freud, Sigmund. Civilization and Its Discontents. Trans. David McLintock. London: Penguin, 2002.

---. Group Psychology and the Analysis of the Ego. Trans. James Strachey. New York: W.W. Norton \& Company, 1975.

Fuster Morell, Mayo. "The Free Culture and 15M Movements in Spain: Composition, Social Networks and Synergies." Social Movement Studies: Journal of Social, Cultural and Political Protest 11.3/11.4 (2012): 386-392.

Garlinger, Patrick Paul. "Sex Changes and Political Transitions; or, What Bibi Andersen Can Tell Us About Democracy in Spain." in Traces of Contamination: Unearthing the Francoist Legacy in Contemporary Spanish Discourse. Eds. Eloy Merino and H. Rosi Song. Lewisburg, PA: Bucknell University Press, 2005. 27-52.

García, Rocío. "Martín Patino retrata la felicidad callejera del 15-M.” El País 21 October 2012. Web. 3 May 2014.

Gili, Margarita, Sanjay Basu, Martin McKee, and David Stuckler. "The Mental Health Risk of Economic Crisis in Spain: Evidence from Primary Care Centres, 2006 and 2010." European Journal of Public Health 23 (2013): 103-108.

Gunther, Richard, P. Nikiforos Diamandouros, and Hans-Jürgen Puhle, eds. The Politics of Democratic Consolidation: Southern Europe in Democratic Perspectives. Cambridge: Cambridge University Press, 1995.

Labanyi, Jo. "Doing Things: Emotion, Affect, and Materiality." Journal of Spanish Cultural Studies 11.3/11.4 (September/December 2010): 223-233.

Labrador Méndez, Germán. "Las vidas subprime. La circulación de historias de vida 
como tecnología de imaginación política en la crisis española (2007-2012).” Hispanic Review 80.4 (Fall 2012): 557-581.

López, Isidro, and Emmanuel Rodríguez. "The Spanish Model." Trans. Brian Anglo. New Left Review 69 (May-June 2011): 5-29.

Lopez-Bernal, James A., Antonio Gasparrini, Carlos M. Artundo, and Martin McKee. "The Effect of the Late 2000s Financial Crisis on Suicides in Spain: An Interrupted Time-Series Analysis." European Journal of Public Health 5 (October 2013): 732736.

Martín-Cabrera, Luis. "The Potentially of the Commons: A Materialist Critique of Cognitive Capitalism from the Cyberbracer@s to the Ley Sinde." Hispanic Review 80.4 (Autumn 2012): 583-605.

Martínez, Guillem, ed. CT o la Cultura de la Transición. Crítica a 35 años de cultura española. Kindle Edition. Madrid: Debolsillo, 2012.

McDonough, Peter, Samuel H. Barnes, and Antonio López Pina. The Cultural Dynamics of Democratization in Spain. Ithaca, NY: Cornell University Press, 1998.

McKee, Martin, Marina Karanikolos, Paul Belcher, and David Stuckler. "Austerity: A Failed Experiment on the People of Europe." Clinical Medicine 12.4 (2012): 346350 .

Minder, Raphael. "Spanish Upstart Party Said it Could, and Did. Now that Hard Part Begins." New York Times 29 May 2014. Web. 31 May 2014.

Moreno-Caballud, Luis. "Cultures of Anyone. The Spanish 'Indignado' Movement and its Contexts." Culturas de cualquiera. Blog. 21 October 2013. Web. 15 February 2014.

---. "Podemos: la crisis de un modelo cultural autoritario." Diagonal 16 October 2014. Web. 17 October 2014.

---. "La imaginación sostenible: culturas y crisis económica en la España actual.” Hispanic Review 80.4 (2012): 535-555.

Mouffe, Chantal. "An Agonistic Approach to the Future of Europe." New Literary History 43.4 (Autumn 2012): 629-640.

---. Agonistics: Thinking the World Politically. London: Verso, 2013.

---. "Deliberative Democracy or Agonistic Pluralism." Reihe Politikwissenschaft I Political Science Series 72 (2000): 1-17. 
---. The Democratic Paradox. London: Verso, 2000.

---. "Interview with Chantal Mouffe." Interview with James Martin. Agonistics: Thinking the World Politically. London: Verso, 2013. 229-236.

---. The Return of the Political. London: Verso 1993.

--- On the Political. London, 2005.

Perugorría, Ignacia and Benjamín Tejerina. "Politics of the Encounter: Cognition, Emotions, and Networks in the Spanish 15M." Current Sociology 61.4 (July 2013): 424-442.

Roca, Miguel, Margarita Gili, Javier García-Campayo, Mauro García-Toro. "Economic Crisis and Mental Health in Spain." The Lancet 382.9909 (December 2013): 19771978.

Rodríguez, Emmanuel. Hipótesis democracia. Quince tesis para la revolución anunciada. Madrid: Traficantes de Sueños, 2013.

Rothkopf, David. Power, Inc.: The Epic Rivalry Between Big Business and Government-and the Reckoning That Lies Ahead. New York: Farrar, Straus and Giroux, 2013.

---. Superclass: The Global Power Elite and the World They Are Making. New York: Farrar, Straus and Giroux, 2009.

Standing, Guy. A Precariat Charter: From Denizens to Citizens. London: Bloomsbury, 2014.

---. The Precariat: The New Dangerous Class. London: Bloomsbury, 2014.

Subirats, Eduardo. Después de la lluvia. Sobre la ambigua modernidad española. Madrid: Temas de Hoy, 1993.

Tsianos, Vassilis, and Dimitris Papadopoulos. "Precarity: A Savage Journey to the Heart of Embodied Capitalism." Transversal (October 2006).

West, Cornel. Interview by Amy Goodman. Democracy Now! 29 September 2011. Web. 2 June 2014.

http://www.democracynow.org/blog/2011/9/29/cornel_west_on_occupy_wall_street_its_t he_makings_of_a_us_autumn_responding_to_the_arab_spring 